Journal of Physical Science, Vol. 29(Supp. 2), 175-184, 2018

\title{
Emulsion Liquid Membrane for Textile Dyes Removal: Extraction Process
}

\author{
Adhi Kusumastuti, ${ }^{1 *}$ Samsudin Anis, ${ }^{1}$ Rodia Syamwil ${ }^{1}$ and Abdul Latif Ahmad ${ }^{2}$ \\ ${ }^{1}$ Faculty of Engineering, Universitas Negeri Semarang, Kampus UNNES Sekaran, \\ Semarang 50229 Indonesia \\ ${ }^{2}$ School of Chemical Engineering, Universiti Sains Malaysia, Engineering Campus, \\ 14300 Nibong Tebal, Pulau Pinang, Malaysia
}

*Corresponding author: adhi_kusumastuti@mail.unnes.ac.id

Published online: 30 July 2018

To cite this article: Kusumastuti, A. et al. (2018). Emulsion liquid membrane for textile dyes removal: Extraction process. J. Phys. Sci., 29(Supp. 2), 175-184, https://doi.org/10.21315/ jps2018.29.s2.13

To link to this article: https://doi.org/10.21315/jps2018.29.s2.13

\begin{abstract}
The minimum facility of wastewater treatment in batik home industry raises an environmental problem. Application of emulsion liquid membrane (ELM) in recovering textile dyes from industrial liquid waste is still an important alternative to solve the problem. Conventional ELM technology has problems of emulsion stability as well as used emulsion breaking. ELM system under Taylor-Couette column (TCC) offers solution for emulsion stability. Emulsion was prepared by using Span 80 as surfactant, kerosene as diluent, and hydrogen chloride as internal phase solution. Real batik industry wastewater was employed as external feed phase solution. Emulsion was produced using ultrasonic probe. The obtained emulsion was then mixed with the external feed solution in TCC. After extraction process, the sample was taken. The raffinate was taken to test final concentration of textile dye. The highest extraction efficiency of $99.4 \%$ was obtained from the system composed of external phase $\mathrm{pH}$ of 10 and $\mathrm{HCl}$ concentration of $0.5 \mathrm{M}$.
\end{abstract}

Keywords: Emulsion liquid membrane, Taylor-Couette column, textile dyes, wastewater, dyes removal

\section{INTRODUCTION}

Being listed in the intangible cultural heritage of humanity, the demand of batik has seen a significant increase. Batik refers to fabric made by applying wax-resist dyeing technique. The motif is made either by drawing dots and lines using canting

(C) Penerbit Universiti Sains Malaysia, 2018. This work is licensed under the terms of the Creative Commons Attribution (CC BY) (http://creativecommons.org/licenses/by/4.0/). 
or printing the resist under a copper stamp. The applied wax resists the permeation of dyes; the process follows with the colouring of the fabric, removal of wax in the boiled water, and repetition of waxing and colouring process based on the desired motif and colour.

Traditionally, Indonesian batik is especially made in some areas in Java with various symbolic patterns. Batik home industries play a central role in certain areas, i.e., Pekalongan, Solo, Yogyakarta and Cirebon with its own characteristic pattern and colour. In Pekalongan, batik has improved the local small business economy. It was reported that in 2011 there were about 1,115 batik operators in Pekalongan. ${ }^{1}$ Despite the contribution in economic sector, batik production involves a huge amount of water, including in wax removal and dyeing processes, which contribute to environmental problems. Textile wastewater, available in alkali condition, contains many types of pollutants in high total dissolved solids (TDS) and suspended solids. The most visible contaminant is textile dye. The high consumption of sodium salt resulted in high concentration of sodium in the wastewater. Some heavy metals are also commonly found in the wastewater. ${ }^{2}$ This is because the textile dyes are usually metal-based compounds. ${ }^{3}$ Among the heavy metals available in textile wastewater are $\mathrm{Pb}, \mathrm{Fe}, \mathrm{Cu}, \mathrm{Cd}, \mathrm{Zn}, \mathrm{Ni}$ and $\mathrm{Cr}^{2,3}$ Monthly, a home industry processing 6,000-20,000 pieces fabric may release about 202.4 $\mathrm{m}^{3}$ wastewater. ${ }^{4}$ Unfortunately, within the batik home industry, only about $0.6 \%$ have their own wastewater treatment installation, while the others directly dispose their wastewater to the water body. ${ }^{1}$

Emulsion liquid membrane (ELM) is a promising alternative to liquid-liquid extraction process that is effectively applied to recover various acid/base, metals and dyes. ${ }^{5-10}$ The application of ELM in the recovery of textile dyes from industrial liquid waste is an interesting topic to be examined. A comprehensive study in the production of optimal emulsion has been done to efficiently recover the textile dyes. Previous research showed that the developed Taylor-Couette column (TCC) was effective to recover textile dyes from simulated wastewater. ${ }^{10}$ TCC was designed to overcome the limitations of conventional stirred vessel. It has been known that extraction under stirred vessel is facing problem of emulsion instability. The system requires high extraction speed to enhance its efficiency. However, running the stirred vessel in high speed could be detrimental to the emulsion. The entrapped solute would be released back through the broken membrane resulting in low extraction efficiency. The addition of surfactant that is expected to improve emulsion stability inhibits the penetration of solute, thus lowering extraction performance. 
Solute extraction under TCC is a good potential for minimising membrane breakage and emulsion swelling. ${ }^{11,12}$ The low shear stress offered by TCC decreases emulsion instability, thus providing high extraction efficiency. As in conventional reactor, solute permeation mostly occurs around the stirrer, in which the TCC solute could permeate along the column that contributes to high extraction efficiency. ELM system done in TCC was able to extract almost all of textile dyes within 5 min. ${ }^{10}$ The application of counter rotating system has successfully increased extraction efficiency as well as accelerate extraction process. This in turn would be expected to lower the overall operational costs.

Nevertheless, the obtained result could not show the real condition of industrial textile wastewater as real textile wastewater contains some contaminants. The success of ELM process is determined by the liquid membrane performance. Therefore, further study to examine the performance and selectivity of liquid membrane in recovering textile dyes from real wastewater needs to be carried out.

\section{EXPERIMENTAL}

\subsection{Materials}

The non-ionic surfactant of sorbitan monooleate which is commercially known as Span 80 was used as emulsion stabiliser. Low odour kerosene (Sigma Aldrich) was used as a diluent. Hydrogen chloride solution (37\%, Merck) was used as internal phase. Methylene blue was used as a textile cationic dye. Deionised water was used to prepare all aqueous solutions. The research employed reagents of analytical grade. Span 80, $\mathrm{NaOH}(25 \%)$ and methylene blue were obtained from Merck. The aqueous feed solution was taken from the liquid waste of batik home industry in Pekalongan.

\subsection{Experimental Procedures}

This research offers the recovery of dyes from textile industrial liquid waste using ELM. ELM produced in this work was a water-in-oil-in-water $(\mathrm{W} / \mathrm{O} / \mathrm{W})$ emulsion. It basically consists of three liquid phases, namely external, membrane and internal phases.

In the beginning, the $\mathrm{W} / \mathrm{O}$ emulsion was produced based on optimum condition reported in previous study. ${ }^{13}$ The membrane phase consisted of kerosene and Span 80. An adequate amount of Span 80 was added to kerosene solution and stirred using magnetic stirrer at $500 \mathrm{rpm}$ for $5 \mathrm{~min}$ to ensure the homogeneity of membrane 
phase solution. The ultrasonic emulsification was preceded by combining internal and membrane phase solution in the volume ratio of 1:3. Standard emulsion was produced by applying Span 80 in the concentration of $4 \mathrm{wt} \%$ and hydrogen chloride solution with concentration $0.05 \mathrm{M}$. The mixture was sonicated for $15 \mathrm{~min}$ in a double glass cylindrical jacket, allowing water-cooling of the emulsification cell. The obtained emulsion was then used to extract solute from external feed phase.

The feed phase solution was then characterised under UV-Vis spectrophotometer. Extraction process was executed in a TCC by varying some parameters and operational conditions involving volume ratio of emulsion to feed phase, extraction time and extraction speed. In all experiments, the TCC was rotated at various speeds whereas the inner cylinder rotation was fixed at a constant speed of 600 rpm. ${ }^{11}$ Table 1 provides detail parameters and operational conditions applied in this study. Once the extraction process was completed, the sample was taken. The raffinate was taken to test the final concentration of textile dye. Carrier, stripping and diluent selections were considered based on their performance in extracting methylene blue, with parameter of extraction efficiency, obtained by the following equation:

$$
\text { Extraction efficiency }=\frac{C_{A, I I}^{0}-C_{A, I I I}}{C_{A, I I I}^{0}} \times 100 \%
$$

where $C_{A, I I I}^{0}=$ concentration of initial feed phase solution, and $C_{A, I I I}=$ concentration of final feed phase solution.

In the meantime, the selectivity of two solutes, $S$, is determined by the following relation: ${ }^{14}$

$$
S_{\frac{M_{1}}{M_{2}}}=\frac{K_{M_{1}}\left[S_{F}^{O}\right]_{M_{1}}}{K_{M_{2}}\left[S_{F}^{O}\right]_{M_{2}}}
$$

where subscripts $M_{1}$ and $M_{2}$ refer to the two solutes, $K$ are the total overall masstransfer coefficients, while $\left[S_{F}^{O}\right]_{M_{1}}$ and $\left[S_{F}^{O}\right]_{M_{2}}$ are the initial concentrations of two solutes in the external feed solution.

Fisher Scientific Accumet $\mathrm{AB} 15 \mathrm{pH}$ meter was used to measure $\mathrm{pH}$ of aqueous solutions. The concentration of remaining methylene blue in the raffinate phase and strip solution was determined spectrophotometrically using UV-Vis spectrophotometer. 
Table 1: Extraction parameters and operation conditions.

\begin{tabular}{lll}
\hline No & Parameters/operation conditions & Values \\
\hline 1 & Volume ratio of emulsion to feed phase & $1 / 9-1 / 3$ \\
2 & Extraction time (min) & $1-30$ \\
3 & Extraction speed: & \\
& Inner cylinder rotation speed (rpm) & 600 \\
& Outer cylinder rotation speed (rpm) & $0-600$ \\
\hline
\end{tabular}

\section{RESULTS AND DISCUSSION}

Solute removal within ELM system is governed by $\mathrm{pH}$ of external feed phase. The formation of solute-carrier complex in the interface of external and membrane phase is affected by solution $\mathrm{pH}$. The complex will only be built at suitable $\mathrm{pH}$, which then diffuses very well through membrane phase towards internal stripping phase. According to some literature works, complex formation rate is strongly affected by external phase $\mathrm{pH} .{ }^{15}$ Moreover, $\mathrm{pH}$ difference between external and internal phase might act as driving force for the extraction process. In the present study, effect of $\mathrm{Na}_{2} \mathrm{CO}_{3}$ concentration as the driving force for methylene blue extraction was investigated at $\mathrm{pH}$ of $8-12$ while the internal phase concentration was kept constant at $\mathrm{HCl}$ concentration of $0.5 \mathrm{M}$. Figure 1 describes the performance of methylene blue extraction under different $\mathrm{Na}_{2} \mathrm{CO}_{3}$ concentration. It could be seen that extraction efficiency increased with the increase of solution $\mathrm{pH}$ from 8 to 10. However, further increase in $\mathrm{Na}_{2} \mathrm{CO}_{3}$ concentration resulted in significant decrease of extraction efficiency. Although theoretically higher $\mathrm{pH}$ gradient is favourable for the extraction process, $\mathrm{pH}$ gradient may induce emulsion swelling. The decrease of extraction efficiency with the increase of external phase $\mathrm{pH}$ could be driven by emulsion swelling phenomenon. It involves the transport of water from external feed phase towards internal stripping phase, leading to membrane leakage, resulting in the release of entrapped solute back to external feed phase. ${ }^{16}$ Therefore, based on the result, further experiment would be done in external phase $\mathrm{pH}$ of 10 . 


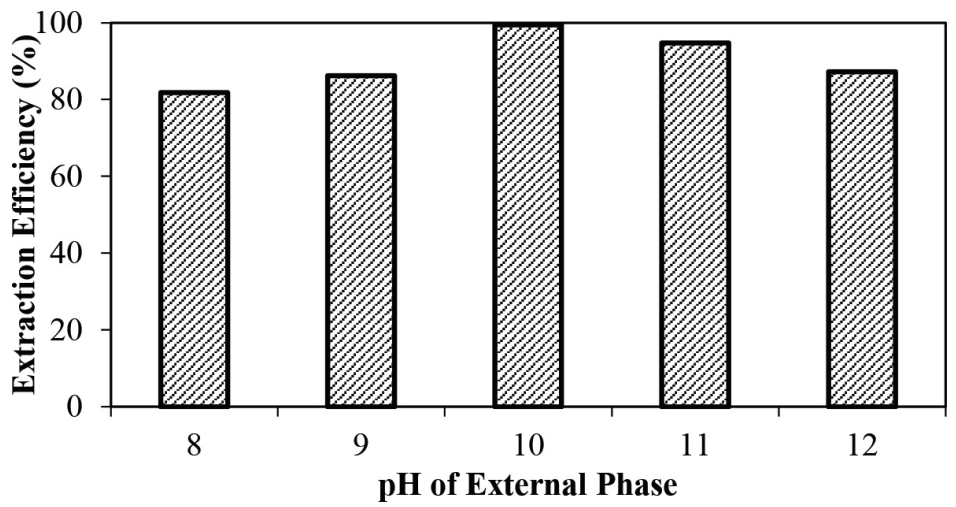

Figure 1: Effect of external phase $\mathrm{pH}$ to extraction efficiency.

Study was continued to examine the effect of $\mathrm{HCl}$ concentration in the internal phase, i.e., from $0.1 \mathrm{M}$ to $0.6 \mathrm{M}$ on extraction efficiency. Figure 2 shows that the highest extraction efficiency obtained using emulsion contained $0.5 \mathrm{M} \mathrm{HCl}$. The $\mathrm{pH}$ gradient between stripping solution and external feed phase solution acted as driving force of the process thus ensure methylene blue permeation towards the internal stripping solution. At $\mathrm{HCl}$ concentration of $0.1 \mathrm{M}$ to $0.4 \mathrm{M}$, the hydrogen ions chemical potential difference between internal and external phase was not enough to trigger solute transfer into internal phase; therefore within this range, the system could not reach optimal extraction efficiency. Higher $\mathrm{HCl}$ concentration resulted in higher extraction rate as was also found by some other researchers. ${ }^{17-19}$ However, higher concentration of $0.6 \mathrm{M}$ resulted in lower extraction efficiency. Some researchers acquired swelling phenomena provoked by water permeation through membrane phase due to excessive osmotic pressure difference between internal and external phase. ${ }^{8,19,20}$ In addition, too high $\mathrm{pH}$ gradient also increased the potential of membrane breakage thus reduced extraction efficiency. ${ }^{21,22}$ 


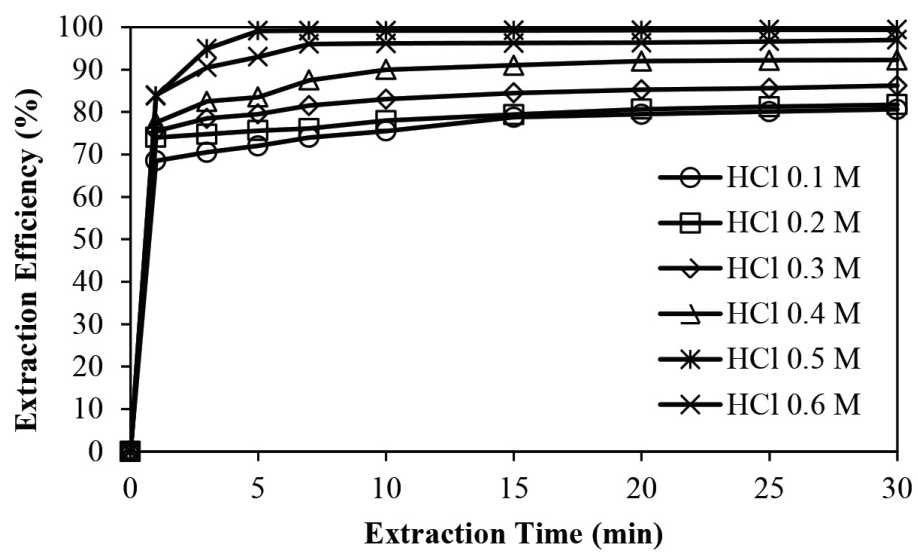

Figure 2: Effect of $\mathrm{HCl}$ concentration to extraction efficiency.

ELM method offers selective separation of solute. Solubility and diffusion of solute do not solely affect the selectivity. Naturally, selectivity is governed by carrier properties. Figure 3 shows that the selectivity of methylene blue is higher than that of others. Almost all of the methylene blue available in feed phase could be extracted within 35 min. Considering the extraction mechanism of solute, the overall system was able to reach high selectivity. This result confirms that obtained by Zhou who studied arsenic and strontium recovery from wastewater with efficiency of $96 \% .{ }^{23}$

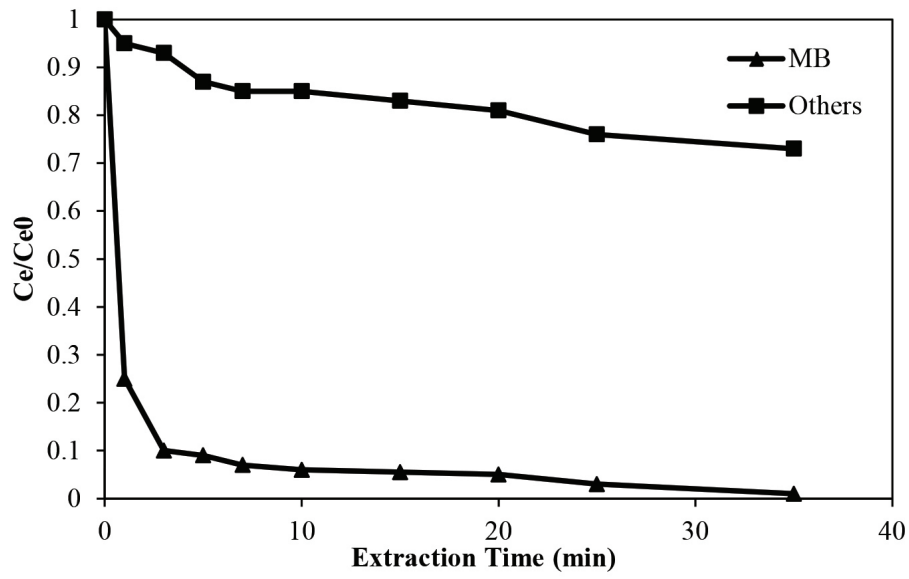

Figure 3: Selectivity of methylene blue to other dyes. 


\section{CONCLUSION}

A comprehensive study on emulsion liquid membrane for textile dyes removal has been done. The investigation succeeded in extracting methylene blue under the parameters of external phase $\mathrm{pH}$, internal phase concentration and extraction time. The optimal result was obtained in external phase $\mathrm{pH}$ of 10 and $\mathrm{HCl}$ concentration of $0.5 \mathrm{M}$. Almost all of methylene blue was removed from the external feed phase within $35 \mathrm{~min}$. The selectivity of methylene blue was higher than that of others.

\section{ACKNOWLEDGEMENTS}

Penelitian Unggulan Perguruan Tinggi Research Grant from Ministry of Research, Technology, and Higher Education of Indonesia (084/SP2H/LT/DRPM/IV/2017) and International Collaboration Research Grant from Universitas Negeri Semarang (DIPA-042.01.2.400899/2017) are gratefully acknowledged.

\section{REFERENCES}

1. Fajri, P. Y. N. (2013). Spatial modeling for determining the location of the wastewater treatment plant of batik industry in pekalongan, Central Java. Master diss., Institut Pertanian Bogor, Bogor, Indonesia.

2. Hussain, J., Hussain, I. \& Arif, M. (2004). Characterization of textile wastewater. J. Ind. Poll. Contr., 20(1), 137-144.

3. Jaishree \& Khan, T. I. (2014). Monitoring of heavy metal in textile waste water of Sanganer, Jaipur (Rajasthan). Int. J. Sci. Res. Publ., 4(3), 1-4.

4. Nindita, V., Purwanto \& Sutrisnanto, D. (2012). Evaluation of eco-efficiency implementation in a batik home industry in pekalongan regency. J. Ris. Teknol. Penc. Pencem. Ind., 2(2), 82-91.

5. Cahn, R. P. \& Li, N. N. (1974). Separation of phenol from waste water by the liquid membrane technique. Sep. Sci., 9(6), 505-519, https://doi. org/10.1080/00372367408055596.

6. Ahmad, A. L. et al. (2013). Emulsion liquid membranes for cadmium removal: Studies of extraction efficiency. Membr. Water Treat., 4(1), 15, https://doi.org/10.12989/mwt.2013.4.1.011.

7. Fouad, E. A. (2008). Zinc and copper separation through an emulsion liquid membrane containing di-(2-ethylhexyl) phosphoric acid as a carrier. Chem. Eng. Technol., 31(3), 370-376, https://doi.org/10.1002/ceat.200700433. 
8. Kageyama, T., Matsumiya, H. \& Hiraide, M. (2004). Separation of traces of heavy metals from an iron matrix by use of an emulsion liquid membrane. Anal. Bioanal. Chem., 379(7-8), 1083-1087, https://doi.org/10.1007/ s00216-004-2669-z.

9. Das, C. et al. (2008). Removal of dyes and their mixtures from aqueous solution using liquid emulsion membrane. J. Hazard. Mater., 159(2-3), 365-371, https://doi.org/10.1016/j.jhazmat.2008.02.027.

10. Kusumastuti, A., Syamwil, R. \& Anis, S. (2016). Emulsion liquid membrane for textile dye removal: Stability study. Paper presented at the Engineering International Conference 2016, Semarang, Indonesia.

11. Ahmad, A. L. et al. (2014). Emulsion liquid membrane based on a new flow pattern in a counter rotating taylor-couette column for cadmium extraction. Sep. Purif. Technol., 127, 46-52, https://doi.org/10.1016/j. seppur.2014.02.029.

12. Park, Y. (2006). Development and optimization of novel emulsion liquid membranes stabilized by non-newtonian conversion in taylor-couette flow for extraction of selected organic and metallic contaminants. $\mathrm{PhD}$ diss., Georgia Institute of Technology, Atlanta, United States.

13. Kusumastuti, A., Syamwil, R. \& Anis, S. (2017). Emulsion liquid membrane for textile dye removal: Stability study. AIP Conf. Proceed., 1818(1), 020026, https://doi.org/10.1063/1.4976890.

14. Kislik, V. (ed.). (2009). Liquid membranes: Principles and applications in chemical separations and wastewater treatment. Amsterdam: Elsevier.

15. Kargari, A. et al. (2004). Batch extraction of gold(III) ions from aqueous solutions using emulsion liquid membrane via facilitated carrier transport. $J$. Membr. Sci., 233(1-2), 1-10, https://doi.org/10.1016/j.memsci.2003.09.027.

16. Wan, Y. \& Zhang, X. (2002). Swelling determination of w/o/w emulsion liquid membranes. J. Membr. Sci., 196(2), 185-201, https://doi.org/10.1016/ S0376-7388(01)00554-3.

17. Matsumiya, H., Kageyama, T. \& Hiraide, M. (2004). Multielement preconcentration of trace heavy metals in seawater with an emulsion containing 8-quinolinol for graphite-furnace atomic absorption spectrometry. Anal. Chim. Acta, 507(2), 205-209, https://doi.org/10.1016/j. aca.2003.11.038.

18. Othman, N., Mat, H. \& Goto, M. (2006). Separation of silver from photographic wastes by emulsion liquid membrane system. J. Membr. Sci., 282(1-2), 171-177, https://doi.org/10.1016/j.memsci.2006.05.020.

19. Kankekar, P. S., Wagh, S. J. \& Mahajani, V. V. (2010). Process intensification in extraction by liquid emulsion membrane (LEM) process: A case study enrichment of ruthenium from lean aqueous solution. Chem. Eng. Process. Process Intens., 49(4), 441-448, https://doi.org/10.1016/j.cep.2010.02.005. 
20. Fouad, E. A. \& Bart, H. J. (2008). Emulsion liquid membrane extraction of zinc by a hollow-fiber contactor. J. Membr. Sci., 307(2), 156-168, https:// doi.org/10.1016/j.memsci.2007.09.043.

21. Gasser, M. S., El-Hefny, N. E., \& Daoud, J. A. (2008). Extraction of Co(II) from aqueous solution using emulsion liquid membrane. J. Hazard. Mater., 151(2-3), 610-615, https://doi.org/10.1016/j.jhazmat.2007.06.032.

22. Sabry, R. et al. (2007). Removal of lead by an emulsion liquid membrane. Part 1.Desalin., 212(1-3), 165-175, https://doi.org/10.1016/j.desal.2006.11.006.

23. Zhou, D.-W. (1996). Emulsion liquid membrane removal of arsenic and strontium from wastewater: An experimental and theoretical study. $\mathrm{PhD}$ diss., New Jersey Institute of Technology, New Jersey, United States. 